DOI: $10.34220 /$ issn.2222-7962/2021.1/16

УДК 346.26

\title{
ENTREPRENEURSHIP MOTIVATION IN THE FORESTRY OF RUSSIA
}

\author{
DSc (Economics) S.S. Morkovina ${ }^{1}$ \\ DSc (Economics) N.V. Sirotkina ${ }^{2}$ \\ PhD (Economics) E. Seydinay ${ }^{1}$ \\ 1 - FSBEI HE "Voronezh State University of Forestry and Technologies named after G.F. Morozov", \\ Voronezh, Russian Federation \\ 2 - FSBEI HE "Voronezh State Technical University", Voronezh, Russian Federation
}

\begin{abstract}
The article presents the results of an entrepreneur survey from the standpoint of assessing the effectiveness of forest management in Russia. It has been established that more than a half of the surveyed entrepreneurs consider their forestry business to be low profitable. Entrepreneurs have significant costs for reforestation and forestry work. The reasons for the low efficiency of forestry activities are the lack of measures for motivating entrepreneurs implemented at the state level. The necessity to improve the efficiency of state forest management has been proved. A mechanism built into the forest management system is suggested to motivate forest plot tenants. The motivational mechanism is a complex of incentive and control measures aimed at ensuring the qualitative performance of forestry work with optimal production costs. The use of the motivation mechanism at the regional level enables to provide support to tenants of forest areas performing forestry activities in a quality manner. Differentiated measures of forest user motivation, based on the results of forest activities, have been substantiated. Motivation measures should include financial support, business control and penalties. The necessity to create a motivational fund for financial support of forest area tenants in the regions of Russia has been proved. The measures for the motivation of entrepreneurs, which ensure growing attractiveness of forest exploitation, have been developed.
\end{abstract}

Keywords: entrepreneurship, motivation, forestry, Russia

\section{ПРЕДПРИНИМАТЕЛЬСКАЯ МОТИВАЦИЯ НА ПРИМЕРЕ ЛЕСНОГО ХОЗЯЙСТВА РОССИИ}

\author{
доктор экономических наук С.С. Морковина ${ }^{1}$ \\ доктор экономических наук Н.В. Сироткина ${ }^{2}$ \\ кандидат экономических наук Э. Сейдинай ${ }^{1}$
}

1 - ФГБОУ ВО «Воронежский государственный лесотехнический университет имени Г.Ф. Морозова», г. Воронеж, Российская Федерация

2 - ФГБОУ ВО «Воронежский государственный технический университет», г. Воронеж, Российская Федерация

В статье представлены результаты опроса предпринимателей с позиций оценки эффективности лесопользования в России. Установлено, что более половины опрошенных предпринимателей считают свой лесной бизнес малорентабельным. Предприниматели несут значительные затраты на лесовосстановительные и лесохозяйственные работы. Причинами низкой эффективности лесохозяйственной деятельности является отсутствие мер по мотивации предпринимателей, реализуемых на государственном уровне. Обоснована необходимость повышения эффективности государственного лесопользования. Предложен механизм, встроенный в систему управления лесным хозяйством для мотивации арендаторов лесных участков. Мотивационный механизм - это комплекс стимулирующих и контролирующих мер, направленных на обеспечение качественного выполнения лесохозяйственных работ при оптимальных производственных затратах. Использование механизма мотивации 
на региональном уровне позволяет оказывать поддержку арендаторам лесных участков, осуществляющим лесохозяйственную деятельность на качественном уровне. Обоснованы дифференцированные меры мотивации лесопользователей, основанные на результатах лесохозяйственной деятельности. Меры мотивации должны включать финансовую поддержку, контроль за бизнесом и штрафы. Обоснована необходимость создания мотивационного фонда финансовой поддержки арендаторов лесных участков в регионах России. Разработаны меры по мотивации предпринимателей, обеспечивающие повышение привлекательности лесопользования.

Ключевые слова: Предпринимательство, мотивация, лесное хозяйство, Россия

\section{Introduction}

State forest management is the activities ensuring the rational use, reproduction, and protection of forests.

The current system of forest management in the Russian Federation, on the one hand, is focused on the development of forest management and, on the other hand, the preservation of forests to meet current and future needs of people and society [1]. Forest management of many European and American countries maintains the environmental functions of forests and the economic interests of forest users [2, 3, 4]. At the same time, forest business is economically interested in sustainable forest management, reforestation and maintenance of environmental forest functions [5, 6].

Over the past decade, there has been a significant imbalance in the processes of artificial reforestation and logging on the forestry fund lands throughout the Russian Federation in a whole and at the regional level [7]. Areas of felled forests significantly exceed reforestation areas [8].

The number of forest fires has significantly increased recently in the forests of Russia.

The existing system of forest management in Russia is not economically effective. It is evidenced by the fact that the contribution of forestry to Russia's GDP is $0.8 \%$, while it makes $3.8 \%$ in Sweden, $5.7 \%$ in Finland, and $2.7 \%$ in Canada.

The harvested volume of round timber is $0.4 \mathrm{~m}^{3}$ from one hectare of operational forest area, while this figure is significantly higher in Europe and America, ranging from 0.5 to $2.8 \mathrm{~m}^{3}[9,10]$.

Forest management should be not only a process within the activities of government bodies. It is also a formation of a system of economic relations arising between the state, business and society and concerning the use of forests and its social and economic results.

Лесотехнический журнал 1/2021
In this respect, the current forest management system in Russia does not require the compulsory formation of a system of equivalent economic relations. Moreover it does not encourage the forest business to perform a number of forestry activities, such as reforestation, protection from fires, pests and diseases. Researchers of this issue emphasize that a forest user has no rational motive to observe the long-term interest of the state. The interests of the forest business are economic, and they are associated with the consumption of forest resources, and are diametrically opposed to the state interests aimed at forest conservation [11]. Forest business in Russia carries increased costs. Entrepreneurs not only pay for forest resources, but also carry out forest work on reforestation at their sole cost and expense. There are economic and social support mechanisms to compensate entrepreneurs for their expenses in the forestry of several countries $[12,13]$.

This actualizes the study of condition of business environment and motivation of forest users in the Russian forestry system.

\section{Materials and methods}

The method of expert assessment has been used to determine the effectiveness of the existing forest business support system in Russia. Informational letter with questionnaire cards were sent to the forest enterprises. In total, 254 enterprises operating in the forestry of the Voronezh region of Russia took part in the survey. Statistical methods were used to process the questionnaires.

\section{Results}

It was established (according to a survey of the forest business representatives) that $28 \%$ of enterprises have post-performance losses according to the results of their work for three or more years. More than a half of the surveyed enterprises show low profitabe activity. Only $12 \%$ of the surveyed, enterprises engaged in wood harvesting, have indicated a significant profit 
over the past three years. $80 \%$ of the respondents believe that the reason for the deterioration of financial condition and low attractiveness of the forest business is the costs of reforestation and other forestry work. Low efficiency in forestry contributes to the development of economic crises and liquidation of enterprises. It has been established that only $26 \%$ of the enterprises work in the logging industry for more than five years.

Entrepreneurs believe that the existing forest management system does not ensure sustainable entrepreneurial activities and contributes to the emergence of entrepreneurial risks. Over $69 \%$ of the surveyed entrepreneurs are not satisfied with the existing forest management system (figure 1).

At the same time, only $2 \%$ of the surveyed entrepreneurs took advantage of state support measures (figure 2).

$68 \%$ of forest users have answered negatively to the question "Did you have to take support (informational, consulting or financial) measures?"

Our survey has testified the necessity for both support and motivation of entrepreneurs for carrying out entrepreneurial activities in forestry. The motivation of entrepreneurs to carry out the activities in forestry is based on economic motives consisting in obtaining the maximum entrepreneurial income from the implementation of activities.
However, income generation and its maximization are highly dependent on the costs of doing business. Therefore, entrepreneurs tend to reduce costs for different types of work, which leads to a decrease in the quality of their performance. Talking about forestry, cost savings and reduced quality of work can lead to deterioration in the environmental parameters of forests, decrease in reforestation, increase in the number of damaged forests, etc.

It is known that forest users do not unequivocally relate to the implementation of activities, realizing their economic goals to the prejudice to their environmental and social goals.

At the same time, state forest management is aimed at solving environment and social problems to a greater degree. In this regard, we believe that the state should be interested in motivating entrepreneurs to carry out high-quality forestry activities. A motivational mechanism has been developed to motivate entrepreneurs to perform forestry activities.

The motivational mechanism is a complex of incentive and control measures aimed at ensuring the quality of forestry work, with optimal production costs. The motivational mechanism of forest users to perform forestry operations is shown in figure 3.

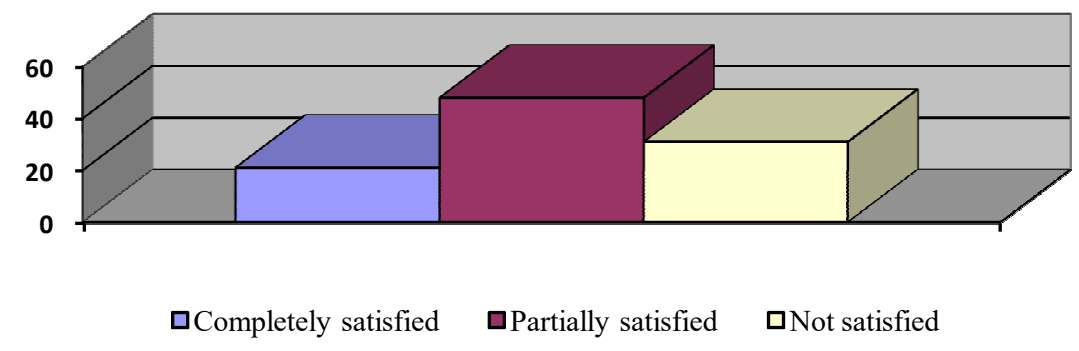

Figure 1. Distribution of forest users according to the degree of satisfaction with the current forest management system

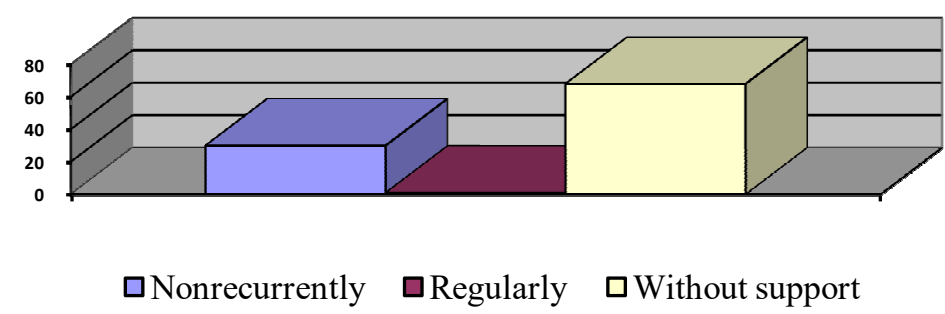

Figure 2. Distribution of forest users by the level of support 


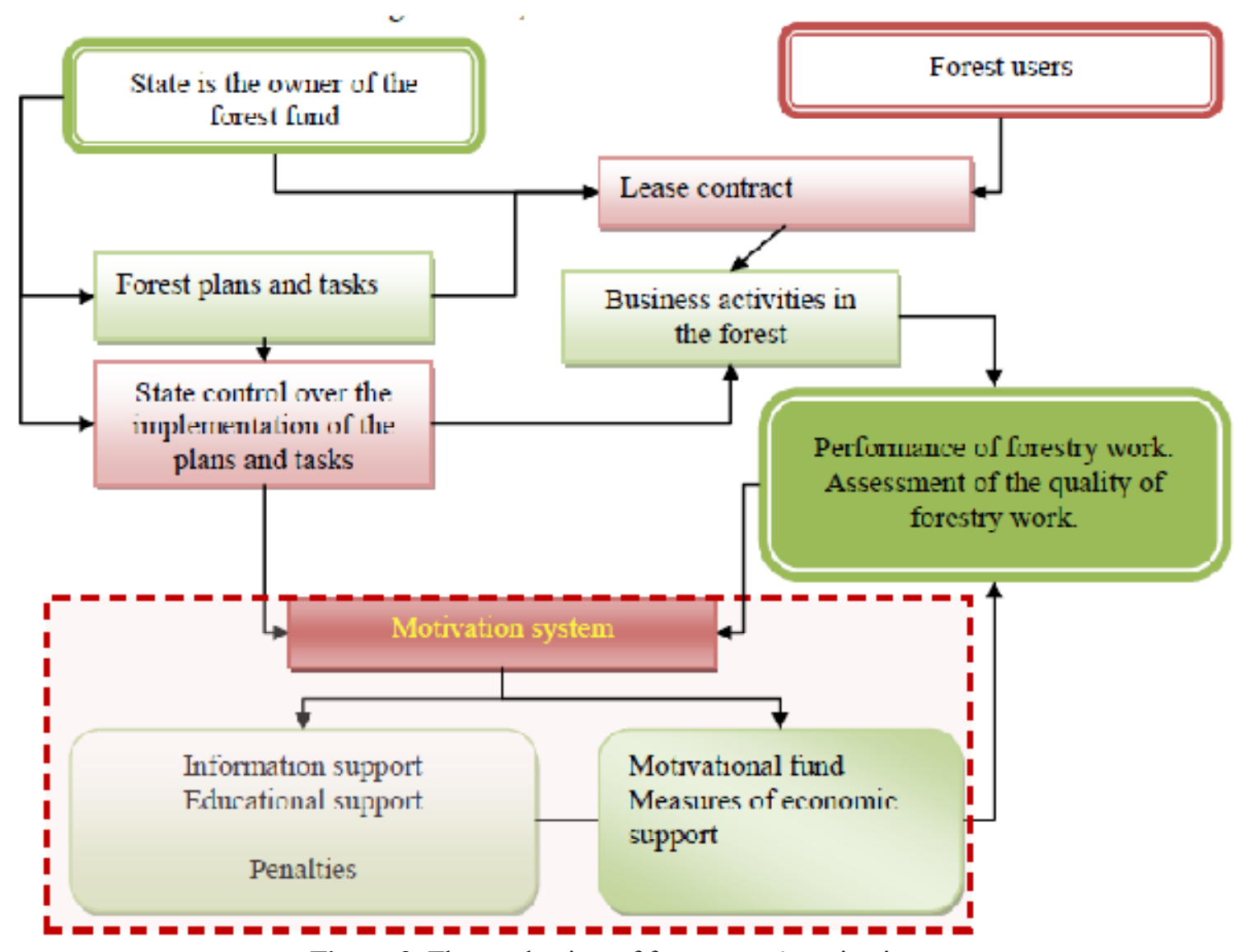

Figure 3. The mechanism of forest users' motivation

Motivation of business activities in forestry is possible using control, economic support measures and penalties.

The proposed motivational mechanism takes into account three objectives of entrepreneurial activity:

- Economic - aimed at generation of long term stable income;

- Ecological - aimed at high-quality implementation of forest management work on reforestation, forest protection from fires, diseases;

- Social - aimed at maintenance of environmental functions in the forest which are places of public recreation.

We have determined the size of the economic support for entrepreneurs working in the forestry of the Voronezh region.

The results of the implementation of forestry activities have been considered to identify entrepreneurs, seeking economic support. The basis was the criteria for the volume and quality of work on reforestation, work on forest care, growing seedlings with improved hereditary properties, protecting the forest from diseases. The total fund of economic motivation for entrepreneurs working in forestry was about $10 \%$ of the rent (table 1). The largest one is the Fund for the motivation of entrepreneurs in the Voronezh region. It amounts to 5680.2 thousand rubles.

The formed motivation fund should be directed to the motivation of entrepreneurs in order to achieve all the indicators of quality and volume of forestry activities by the forest users of the Voronezh region.

Only $66 \%$ of the motivation fund should be directed for the support of forest users in the Kursk region. It has been established that $34.6 \%$ of the plots (in which forest reproduction activities were carried out) do not meet the requirements of forest management.

Not more than $33 \%$ of the motivation fund is received by the forest users in the three regions (Belgorod, Lipetsk and Tambov). Savings (in the billing period) amount to 7.512 million rubles. It has been determined that 6.551 million rubles can be annually spent (maximally) on the motivation of forest tenants. It is not more than $4.0 \%$ of the total amount of pay- 
ments from the use of forests received into the consolidated budget of the Russian Federation. The provision of benefits for forestry entrepreneurship in the field of taxation and partial subsidization of the costs associated with the payment of advance lease payments under equipment leasing contracts is an effective motivational measure for the qualitative performance of forestry activities.

\section{Conclusion}

The forestry of Russia is characterized by the absence of effective mechanisms for the motivation of forest users to implement forestry activities. Forest users and the state interact in the forest management system, but they have multidirectional goals, which negatively affect the development of the country's forestry. The mechanism of motivation developed by us corresponds to the environmental, economic and social goals of forestry. Its use (at the regional level) enables to provide support to tenants of forest areas who perform forestry activities in a quality manner.

Economic interests of all the forest users must be viewed from the perspective of entrepreneurial income generation and the ability to fulfill the responsibilities of reforestation imposed on the entrepreneur. Therefore, motivation measures should be different and include financial support, control and fines. It is necessary to create motivational funds for the financial support of tenants of forest areas in the regions of Russia. The inclusion of a motivational mechanism in the forest management will streamline the processes of control over forest use and help to develop entrepreneurial activities in forestry.

The fund of economic motivation of forest users

\begin{tabular}{lllll}
\hline Regions & $\begin{array}{l}\text { Number } \\
\text { tenants, units }\end{array}$ & $\begin{array}{l}\text { of } \\
\text { the rent for } \\
\text { thousand } \\
\text { roubles }\end{array}$ & $\begin{array}{l}\text { Entrepreneurs } \\
\text { motivation fund funds for motivation, } \\
\text { (total), thousand } \\
\text { roubles }\end{array}$ & $\begin{array}{l}\text { The actual amount of } \\
\text { thousand roubles }\end{array}$ \\
\hline Belgorod region & 133 & 6720.6 & 633.9 & 209.2 \\
\hline Voronezh region & 658 & 135483.9 & 5680.2 & 5680.2 \\
\hline Kursk region & 128 & 11834.3 & 808.9 & 533.8 \\
\hline Lipetsk region & 83 & 3023.7 & 273.9 & 90.38 \\
\hline Tambov region & 30 & 1185.2 & 115.9 & 38.2 \\
\hline Total & & 158245 & 7512.9 & 6551.8 \\
\hline
\end{tabular}

\section{Библиографический список}

1. Morkovina S. S., Zinovyeva I. S., Denisova Yu. G. (2012) Improving analysis tools of organization of forestry. Economic Analysis: Theory and Practice 201240 (295) 58-64.

2. Perevozchikova M., Iskra A., Rojo N. (2015) The perceptions about payment schemes for ecosystem services: Study case of the San Miguel and Santo Tomás Ajusco community. Mexico Ecosystem Services, 14: 27-36.

3. Maetzke F. G., Cullotta S. (2016) Environmental and Forest Planning in Italy: Conflicts and Opportunities. Agriculture and Agricultural Science Procedia, 8: 332-338.

4. Strauch A. M., Rurai M. T., Astier M. (2016) Almedom Influence of forest management systems on natural resource use and provision of ecosystem services in Tanzania. Journal of Environmental Management, 180: 35-44.

5. Keča Lj., Keča N., Pantić D. (2012) Net Present Value and Internal Rate of Return as Indicators for Assessment of Cost-efficiency of Poplar Plantations: a Serbian case study. International Forestry Review, 14(2): 145-157.

6. Canadas M. J., Novais A., Marques M. (2016) Wildfires Forest management and landowners collective action. A comparative approach at the local level. Land Use Policy, 56: 179-188. 


\section{Менеджмент. Экономика. Организация}

7. Morkovina S., Drapalyuk M., Sibiryatkina I., Torzhkov I. (2017) Priorities of diversification in forest complex. Proceedings of the 30th International Business Information Management Association Conference, IBIMA 2017 - Vision 2020: Sustainable Economic development, Innovation Management, and Global Growth. Madrid, 2017.

8. Petrov A. P., Morkovina S. S. (2019) Model of economic organization of the Russian forestry. IOP Conference Series: Earth and Environmental Science, 226: 012041. DOI 10.1088/1755-1315/226/1/012041.

9. Schwartz E., Shmatkov N., Kobyakov. K. (et al.) (2018) Some causes of forest sector crisis and ways out of it. Sustainable forest management, 3 (55): 4-16.

10. Garcia-Gonzalo J., Borges J. G. (2019) Models and tools for integrated forest management and forest policy analysis : An Editorial. Forest Policy and Economics, Vol. 103, pp. 1-3.

11. Morkovina S. S., Denisova Yu. G., Drapalyuk O. I., Shanyan Bao (2013) Forms of support for the development of entrepreneurship in the forest sector of the Central Chernozem Region. Lesotekhnicheskii zhurnal [Forest Engineering journal]. Vol. 3. No. 4 (12), pp. 210-216 (in Russian).

12. Tirivayi N., Nennen L., Wondimagegn Tesfaye, Qiang Ma (2018) The benefits of collective action: Exploring the role of forest producer organizations in social protection. Forest Policy and Economics, 90: 106-114.

13. Nielsen-Pincus M., Ribe R. G., Johnson B. R. (2015) Spatially and socially segmenting private landowner motivations, properties, and management: A typology for the wildland urban interface. Landscape and Urban Planning, Vol. 137, May 2015, pp. 1-12. DOI: https://doi.org/10.1016/j.landurbplan.2014.11.020.

\section{References}

1. Morkovina S. S., Zinovyeva I. S., Denisova Yu. G. (2012) Improving analysis tools of organization of forestry. Economic Analysis: Theory and Practice 201240 (295) 58-64.

2. Perevozchikova M., Iskra A., Rojo N. (2015) The perceptions about payment schemes for ecosystem services: Study case of the San Miguel and Santo Tomás Ajusco community. Mexico Ecosystem Services, 14: 27-36.

3. Maetzke F. G., Cullotta S. (2016) Environmental and Forest Planning in Italy: Conflicts and Opportunities. Agriculture and Agricultural Science Procedia, 8: 332-338.

4. Strauch A. M., Rurai M. T., Astier M. (2016) Almedom Influence of forest management systems on natural resource use and provision of ecosystem services in Tanzania. Journal of Environmental Management, 180: 35-44.

5. Keča Lj., Keča N., Pantić D. (2012) Net Present Value and Internal Rate of Return as Indicators for Assessment of Cost-efficiency of Poplar Plantations: a Serbian case study. International Forestry Review, 14(2): 145-157.

6. Canadas M. J., Novais A., Marques M. (2016) Wildfires Forest management and landowners collective action. A comparative approach at the local level. Land Use Policy, 56: 179-188.

7. Morkovina S., Drapalyuk M., Sibiryatkina I., Torzhkov I. (2017) Priorities of diversification in forest complex. Proceedings of the 30th International Business Information Management Association Conference, IBIMA 2017 - Vision 2020: Sustainable Economic development, Innovation Management, and Global Growth. Madrid, 2017.

8. Petrov A. P., Morkovina S. S. (2019) Model of economic organization of the Russian forestry. IOP Conference Series: Earth and Environmental Science, 226: 012041. DOI 10.1088/1755-1315/226/1/012041.

9. Schwartz E., Shmatkov N., Kobyakov. K. (et al.) (2018) Some causes of forest sector crisis and ways out of it. Sustainable forest management, 3 (55): 4-16.

10. Garcia-Gonzalo J., Borges J. G. (2019) Models and tools for integrated forest management and forest policy analysis : An Editorial. Forest Policy and Economics, Vol. 103, pp. 1-3.

11. Morkovina S. S., Denisova Yu. G., Drapalyuk O. I., Shanyan Bao (2013) Forms of support for the development of entrepreneurship in the forest sector of the Central Chernozem Region. Lesotekhnicheskii zhurnal [Forest Engineering journal]. Vol. 3. No. 4 (12), pp. 210-216 (in Russian). 
12. Tirivayi N., Nennen L., Wondimagegn Tesfaye, Qiang Ma (2018) The benefits of collective action: Exploring the role of forest producer organizations in social protection. Forest Policy and Economics, 90: 106-114.

13. Nielsen-Pincus M., Ribe R. G., Johnson B. R. (2015) Spatially and socially segmenting private landowner motivations, properties, and management: A typology for the wildland urban interface. Landscape and Urban Planning, Vol. 137, May 2015, pp. 1-12. DOI: https://doi.org/10.1016/j.landurbplan.2014.11.020.

\section{Information about authors}

Morkovina Svetlana Sergeevna - DSc (Economics), Vice-Rector for Science and Innovation, FSBEI HE "Voronezh State University of Forestry and Technologies named after G.F. Morozov", Voronezh, Russian Federation; e-mail: tc-sveta@mail.ru.

Sirotkina Natalya Valeryevna - DSc (Economics), Professor, FSBEI HE "Voronezh State Technical University", Voronezh, Russian Federation.

Seydinay Enrik - PhD (Economics), FSBEI HE "Voronezh State University of Forestry and Technologies named after G.F. Morozov", Voronezh, Russian Federation.

\section{Сведения об авторах}

Морковина Светлана Сергеевна - доктор экономических наук, проректор по науке и инновациям ФГБОУ ВО «Воронежский государственный лесотехнический университет имени Г.Ф. Морозова», г. Воронеж, Российская Федерация; e-mail: tc-sveta@mail.ru.

Сироткина Наталья Валерьевна - доктор экономических наук, профессор ФГБОУ ВО «Воронежский государственный технический университет», г. Воронеж, Российская Федерация.

Сейдинай Энрик - кандидат экономических наук, ФГБОУ ВО «Воронежский государственный лесотехнический университет имени Г.Ф. Морозова», г. Воронеж, Российская Федерация. 